\title{
Contents, Vol. 69, No. 3, 1996
}

\section{Recent Advances in Neonatal Medicine}

An International Symposium Honoring K. Riegel Tubingen, April 26-28,1996

Scientific Organization Ch.P. Speer, Tubingen

Extended Abstracts

167 Brain Injury in the Premature Infant: Current Concepts

Volpe, J.J. (Boston, Mass.)

170 Neonatal Organ Damage due to Ischemia Reperfusion

Raivio, K.O. (Helsinki)

172 Host Defense against Infection in the Newborn

Johnston, R.B., Jr. (New Haven, Conn.)

174 Virus Infections in Pregnancy

Peckham, C. (London)

175 Postnatal Infection: Epidemiology, Diagnosis and

Management

Philip, A.G.S. (Palo Alto, Calif.)

178 Postnatal Lung Development and Its Impairment by Glucocorticoids

Tschanz. S.A.; Burri, P.H. (Berne)

180 Biophysical Aspects of the Surfactant System in Relation to Neonatal Lung Function

Robertson, B. (Stockholm)

182 Current Views on the Functions of Surfactant Proteins

van Golde. L.M.G. (Utrecht)

184 Hydrophobic Proteins and Their Analogues in Pulmonary Surfactant

Curstedt, T,; Nilsson, G.; Robertson, B.; Johansson, J. (Stockholm)

186 Where Are We Now with the Prenatal Steroids and Postnatal Surfactant Treatment?

Halliday. H.L. (Belfast)

188 Pathogenesis of Chronic Lung Disease

Speer, Ch.P.; Groneck, P. (Tubingen/Cologne)

190 Oxygen Radical and Tissue Destruction

Saugstad, O.D. (Oslo)

193 Oxygen Toxicity and the Protective Antioxidant Enzyme System of the Lung

Frank, L. (Miami, Fla.)

197 Clinical Interventions in Chronic Lung Disease

Greenough, A. (London)

199 Inhaled Nitric Oxide Treatment

Milner, A.D. (London)

201 Importance of Fetal Perceptions in the Organization of the Mother-Fetus Interactions

Relier. J.-P. (Paris)

210 Resuscitation of the Newborn

Milner, A.D. (London) 
212 Author Index, Extended Abstracts

\section{KAKGEK}

E-Mail karger@karger.ch Fax+41 613061234

CI996S. KargerAG, Basel 0006-3126/96/0693-0165\$ 10.00/0 